\title{
Exploring the differences in cloud properties observed by the Terra and Aqua MODIS Sensors
}

\author{
N. Meskhidze ${ }^{1}$, L. A. Remer ${ }^{2}$, S. Platnick ${ }^{2}$, R. Negrón Juárez ${ }^{3}$, A. M. Lichtenberger ${ }^{1}$, and A. R. Aiyyer ${ }^{1}$ \\ ${ }^{1}$ Marine Earth and Atmospheric Sciences, North Carolina State University, Raleigh, NC, 27695, USA \\ ${ }^{2}$ NASA Goddard Space Flight Center, Greenbelt, MD, 20771, USA \\ ${ }^{3}$ Ecology and Evolutionary Biology, Tulane University, New Orleans, LA, 70118, USA
}

Received: 4 November 2008 - Published in Atmos. Chem. Phys. Discuss.: 16 January 2009

Revised: 14 April 2009 - Accepted: 12 May 2009 - Published: 29 May 2009

\begin{abstract}
The aerosol-cloud interaction in different parts of the globe is examined here using multi-year statistics of remotely sensed data from two MODIS sensors aboard NASA's Terra (morning) and Aqua (afternoon) satellites. Simultaneous retrievals of aerosol loadings and cloud properties by the MODIS sensor allowed us to explore morning-toafternoon variation of liquid cloud fraction (CF) and optical thickness (COT) for clean, moderately polluted and heavily polluted clouds in different seasons. Data analysis for sevenyears of MODIS retrievals revealed strong temporal and spatial patterns in morning-to-afternoon variation of cloud fraction and optical thickness over different parts of the global oceans and the land. For the vast areas of stratocumulus cloud regions, the data shows that the days with elevated aerosol abundance were also associated with enhanced afternoon reduction of $\mathrm{CF}$ and COT pointing to the possible reduction of the indirect climate forcing. A positive correlation between aerosol optical depth and morning-to-afternoon variation of trade wind cumulus cloud cover was also found over the northern Indian Ocean, though no clear relationship between the concentration of Indo-Asian haze and morningto-afternoon variation of COT was established. Over the Amazon region during wet conditions, aerosols are associated with an enhanced convective process in which morning shallow warm clouds are organized into afternoon deep convection with greater ice cloud coverage. Analysis presented here demonstrates that the new technique for exploring morning-to-afternoon variability in cloud properties by
\end{abstract}

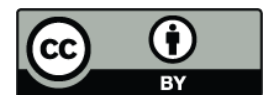

Correspondence to: N. Meskhidze (nmeskhidze@ncsu.edu) using the differences in data products from the two daily MODIS overpasses is capable of capturing some of the major features of diurnal variations in cloud properties and can be used for better understanding of aerosol radiative effects.

\section{Introduction}

It is now well documented that anthropogenic aerosols can alter cloud microphysical and optical properties leading to considerable changes to the earth's radiation budget and climate (Ackerman et al., 2000; Ramanathan et al., 2001; Schwartz et al., 2002; Andreae et al., 2004; Penner et al., 2004; Kaufman et al., 2005a; Koren et al., 2004, 2005). An increase in cloud condensation nuclei $(\mathrm{CCN})$ number concentration from anthropogenic aerosols was shown to yield a higher number of cloud droplets that, for fixed liquid water path (LWP), may lead to a reduced droplet size and thereby enhanced reflectance of solar radiation. This is the so-called first indirect effect of anthropogenic aerosols (Twomey, 1977; Kaufman and Fraser, 1997; Bréon et al., 2002; Feingold et al., 2003). Reduction of cloud droplet size may also inhibit precipitation and increase cloud lifetime, the second indirect effect (Albrecht, 1989; Rosenfeld, 1999, 2000). Studies have also shown that absorbing aerosols, e.g., black carbon and dust can affect clouds semi-directly by evaporating existing cloud droplets through solar (shortwave) absorption and inhibiting cloud formation through suppression of the convection in the boundary layer (Ackerman et al., 2000; Johnson et al., 2004; Erlick and Schlesinger, 2008). Recently Koren et al. (2008) using results from the Amazon basin developed a theoretical basis

Published by Copernicus Publications on behalf of the European Geosciences Union. 
for the opposing effect of aerosols on clouds: the microphysical (i.e. indirect) and the radiative (i.e. semi-direct). A regional climate modeling study of biomass burning aerosol in the Amazon region shows disproportional impact of the smoke on the cloudiness inside and outside the smoke area (Zhang et al., 2008). Furthermore, recent large-eddy simulation (LES) studies on the impact of aerosol on marine stratocumulus clouds revealed that the aerosol induced increase in droplet number concentration can lead to reduction in cloud water and diminishment of indirect cloud forcing (Ackerman et al., 2004; Lu and Seinfeld, 2005; Sandu et al., 2008). It was predicted that enhanced daytime entrainment drying associated with non-precipitating clouds could lead to close to zero or even reversal of the sign for the aerosol second indirect effect (Ackerman et al., 2004; Lu and Seinfeld, 2005). Elucidation of the effects of natural and anthropogenic aerosols on clouds and analysis of these variations in space and time is crucial for improved understanding and predicting climate change (Forest et al., 2002; Knutti et al., 2002; Anderson et al., 2003).

Today, the relative importance of indirect and semi-direct effects in the earth's energy budget and hydrological cycle remain poorly quantified and therefore our ability to represent these effects in global models is hampered. To unravel the intricate mechanisms by which perturbations in aerosols lead to perturbations in cloud properties it is necessary to seek more knowledge of aerosol-cloud interaction using modeling, remotely sensed data and in situ observations. Satellite platforms have been widely used for characterization of cloud properties in different parts of the globe. The network of operational satellites available from the mid1980s can provide global observations of aerosols and clouds with high spatial and temporal resolution. Satellite measurements have demonstrated strong systematic correlations among aerosol loading, cloud cover and cloud height over the Atlantic Ocean (Kaufman et al., 2005a; Koren et al., 2005) and Europe (Devasthale et al., 2005). It was also shown, that heavy smoke over the Amazon forest (Koren et al., 2004; Feingold et al., 2005) and pollution over China (Krüger and Graß1, 2004) decrease the cloud cover by heating the atmosphere and cooling the surface. However, remotely sensed studies of the second indirect or semidirect effects of aerosols are challenging, because boundary layer air masses that exhibit different aerosol properties usually have different histories and are invariably subject to covarying meteorological conditions, making it difficult to disentangle signals associated with aerosol and purely dynamical forcing. Cloud contamination may also cause a false relationship between the retrievals of cloud properties and aerosol optical depth (AOD) (Kaufman et al., 2005b; Brennan et al., 2005).

In this study, the two Moderate Resolution Imaging Spectroradiometer (MODIS) sensors aboard NASA's Terra and Aqua satellites are used for characterization of cloud development and identification of processes affecting cloud formation. With $3 \mathrm{~h}$ differences in equatorial crossing times
(10:30 for Terra and 13:30 for Aqua), the MODIS sensors offer an unprecedented opportunity to study the morning-toafternoon variability of cloud properties and the effect of different processes on cloud development in different parts of the globe. In addition to cloud fraction, cloud-top temperature and pressure, effective radius, optical thickness and the thermodynamic cloud phase, MODIS also provides systematic and accurate information on AOD and the contribution to the optical thickness by the fine mode (Tanré et al., 1997; King et al., 1999, 2003; Remer et al., 2005). Therefore the combination of the MODIS instruments can be used to study spatial and temporal variability in aerosols and clouds as well as their possible interaction, significantly enhancing the current capability of remote sensing from space-borne observations.

\section{Data and methodology}

In this study we use the MODIS Collection 5 (C5) Level-3 global daily gridded products averaged at $1^{\circ} \times{ }^{\circ}$ (longitude and latitude) resolution. The $\mathrm{C} 5$ data is generated using recently updated operational cloud and aerosol retrieval algorithms and is the most up to date dataset available for the MODIS retrievals (Hubanks et al., 2008). MODIS measures radiances in 36 spectral bands from 0.4 to $14.24 \mu \mathrm{m}$ and has a swath width of $2330 \mathrm{~km}$. The spatial resolution at nadir has the following ranges: $250 \mathrm{~m}$ ( 2 channels), $500 \mathrm{~m}$ (5 channels), and $1 \mathrm{~km}$ (29 channels). The aerosol retrieval makes use of the first seven of these channels $(0.47-2.13 \mu \mathrm{m})$ while additional wavelengths in other parts of the spectrum are used to identify cloud properties and ocean products (Esaias et al., 1998; Platnick et al., 2003; Remer et al., 2005). MODIS daily mean for AOD and quality assured (QA)weighted means for liquid cloud products (cloud retrieval fraction, CF, and optical thickness, COT) from July 2002 to December 2007 are used in the present analysis. Only the data with available retrievals from both Terra and Aqua satellite sensors are used in the analysis.

To quantify the effects of aerosols on the evolution of warm clouds we examine morning-to-afternoon variation of $\mathrm{CF}$ and COT in association with the abundance of aerosols. Morning-to-afternoon variation of cloud properties is captured by subtracting MODIS Aqua data products (MYD08_D3) from corresponding MODIS Terra retrievals (MOD08_D3). This method is similar to one used by Han et al. (1994) to quantify morning-to-afternoon contrast in cloud effective radii and optical thickness. Due to the relatively short time scale between MODIS overpasses $(\sim 3 \mathrm{~h}$ near the equator) such a procedure can be viewed as a high pass temporal filter largely removing the effects of synoptic and the large scale processes. Furthermore, since the results shown here represent averages over 7 years, it is anticipated that day-to-day weather variations - which can be effectively considered to be stochastic "white noise" in this con- 
text (e.g. Rao et al., 1997; Wise and Comrie, 2005) - should not produce systematic bias that could influence the conclusions drawn herein. However, if the morning-to-afternoon variations in cloud amount and LWP are associated with regular meteorological conditions, untangling the responses of clouds to regional-scale variations in aerosol abundances from dynamical forcing becomes increasingly difficult and will be discussed in more details below.

Following the results of Kaufman et al. (2005a) AOD retrievals at $550 \mathrm{~nm}$ will be used as a surrogate for the concentration of aerosols that interact with the cloud affecting its short-term variation and properties. The relationship between aerosol concentration and the morning-toafternoon variation in cloud properties is explored by separating morning-to-afternoon differences in cloud properties into three broad categories based on MODIS retrieved AOD values from the Terra satellite. The episodes with AOD $<0.1$ are quantified as "clean", $0.1 \leq \mathrm{AOD} \leq 0.25$ are considered as "moderately polluted" and $0.25<\mathrm{AOD} \leq 0.8$ is treated as "heavily polluted". Data with AOD $>0.8$ were removed from the analysis to avoid misclassification of clouds and aerosols under high-AOD conditions (Brennan et al., 2005). The AOT $\approx 0.25$ is used here as a transitional value between moderately and heavily polluted regimes in accordance to the recent observations for the optimal cloud development (Koren et al., 2008; Rosenfeld et al., 2008). To factor out potential dynamical and other local effects, the data are further stratified by typical cloud types (stratocumulus and trade cumulus) and locations (ocean and land). Although MODIS measures the aerosol optical thickness in cloud-free (sun-glint-free) conditions, simultaneous observations of aerosols in cloud-free regions of the grid box and clouds in the cloudy regions of the grid box are possible (Kaufman et al., 2005a). When no AOD data is available for a given grid box, cloud products are removed from the analysis. Several case studies were also carried out to examine the vertical distribution of aerosols with respect to clouds (i.e. to quantify if aerosols are below, in, or advecting above the cloud layers).

It should be noted that cloud contamination of aerosol retrievals (particularly for higher AOD samples) has been discussed in the literature (Kaufman et al., 2005b) and could potentially lead to a positive correlation between cloud fraction and aerosol optical depth. To reduce possible artifacts in the satellite retrievals that might influence our results we took the following steps. First, we restricted the data to AOD less than 0.8 (Brennan et al., 2005). This eliminates the possibility that heavy aerosol is mistakenly classified as a cloud. The histograms for AOD distribution were examined in the study regions to assure that the amount of data removed using AOT threshold is minor and is not expected to introduce any spatial and temporal biases in data analysis (see Supplementary material Fig. S1: http://www.atmos-chem-phys.net/9/3461/ 2009/acp-9-3461-2009-supplement.pdf). In addition, the MODIS cloud mask used in the aerosol retrieval (Martins et al., 2002) automatically rejects the first layer of non-cloudy pixels surrounding a cloud. This reduces the probability for both cloud contamination and contribution of highly humidified aerosols (Koren et al., 2005). Finally, we have carried out comparison of MODIS AOD with AERONET (Holben et al., 1998) observations in the vicinity of selected stratocumulus regions (at San Nicolas Island off the coast of California and Ascension Island in South Atlantic) (see Supplementary material Fig. S2: http://www.atmos-chem-phys.net/9/ 3461/2009/acp-9-3461-2009-supplement.pdf) to show, that there were no significant differences for episodes with higher AOD.

For a study in which multiple satellite sensors are employed it is crucial to correctly estimate cross-platform agreement and accuracy. The two MODIS instruments and the algorithms applied to the MODIS-measured radiances for both aerosols and clouds are designed to be identical; although, it has been shown that spectral bands in the two instruments have differences (e.g. spatial/spectral crosstalk and focal plane alignment differences, see Barnes et al., 2004; Xiong et al., 2004; Remer et al., 2006). Different equatorial crossing times of the two instruments may also influence the viewing geometries and subsequent retrievals (Platnick et al., 2003). Despite this, there are no known large uncertainties or biases in cloud properties retrieved by the two MODIS sensors (Hubanks et al., 2008). Spurious biases and unrealistic skewness that may still be associated with few individual measurements are avoided in this study by examining very large number of MODIS retrievals and looking at the average seasonal patterns in morning-to-afternoon variation of different cloud parameters.

\section{Cloud properties}

Here we analyze geographical and seasonal distributions of morning-to-afternoon differences of warm (liquid) cloud optical and microphysical properties observed by the MODIS sensors. We examine morning-to-afternoon variations in CF and COT for four different seasons: boreal winter (DJF), spring (MAM), summer (JJA) and fall (SON). To capture possible effects of aerosols on morning-to-afternoon variation of cloud properties separate analyses are carried out for clean, moderately polluted and heavily polluted cases. Figures 1 and 2 show that the major morning-to-afternoon variations in CF and COT are observed over subtropical oceans and the three largest rainforests - the American, African, and Asian. Since cloud formation over the oceans and continents is influenced by different dynamic processes, morningto-afternoon variation of clouds are considered separately in three stratocumulus cloud regions over cool subtropical waters off the coast of California (CAL), Peru (PE), and southern Africa (SAF), two trade wind cumuli regions over the Arabian Sea (AS) and the Bay of Bengal (BoB) and the shallow cumulus clouds over the the part of the Amazon basin known as Brazilian Legal Amazon (BLA). 

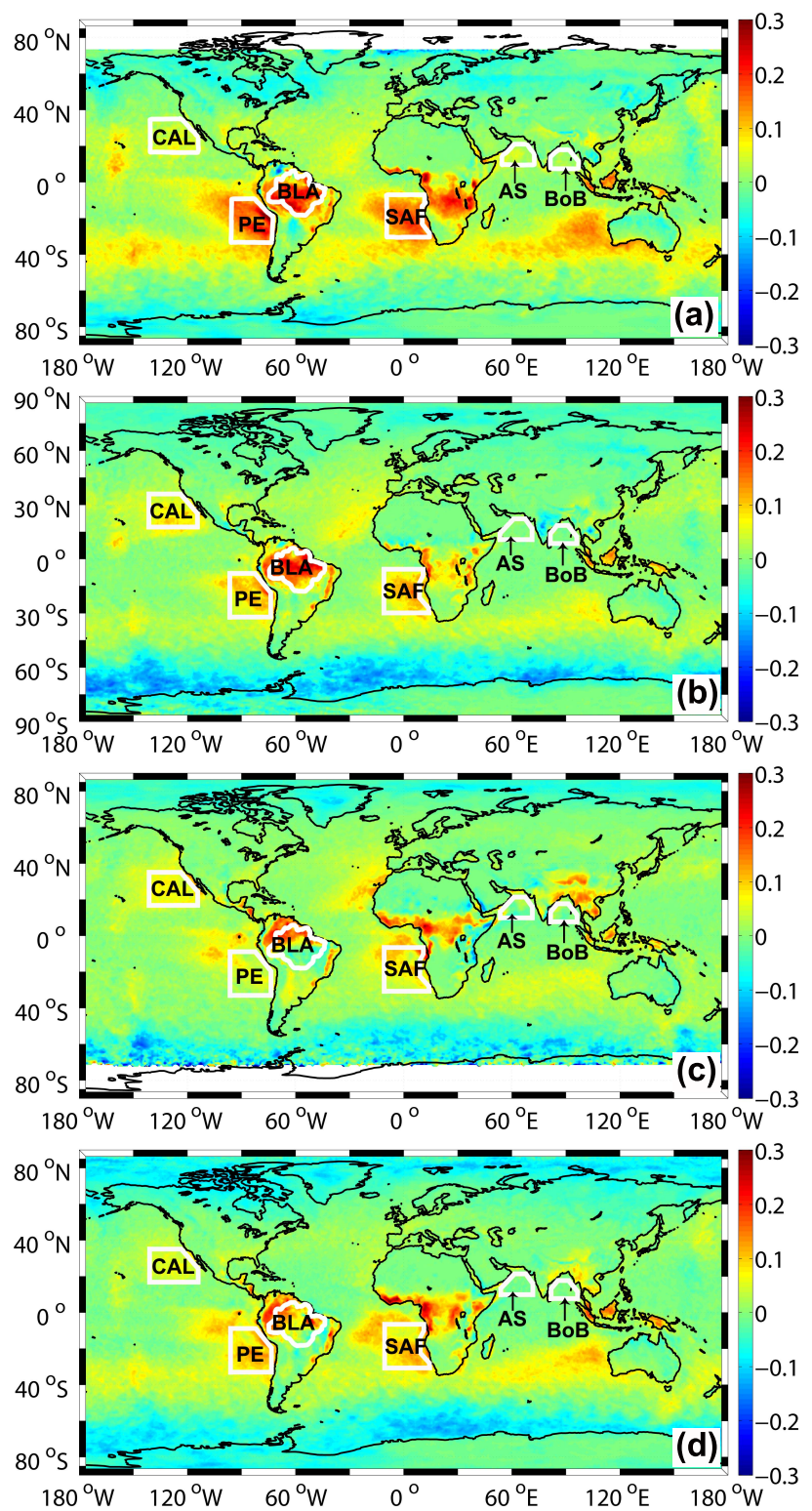

Fig. 1. Global distribution of 7-yr averaged morning minus afternoon values for liquid cloud fraction (CF) for (a) DecemberFebruary; (b) March-May; (c) June-August; and (d) SeptemberNovember. Area surrounded by solid white line illustrates regions chosen for the analysis of morning-to-afternoon variation of cloud properties. Selected areas are: stratocumuluc cloud regions off the coast of California (CAL), Peru (PE) and South Africa (SAF), trade wind comuli regions over Arabian Sea (AS) and Bay of Bengal $(\mathrm{BoB})$ and the part of the Amazon basin known as Brazilian Legal Amazon (BLA).
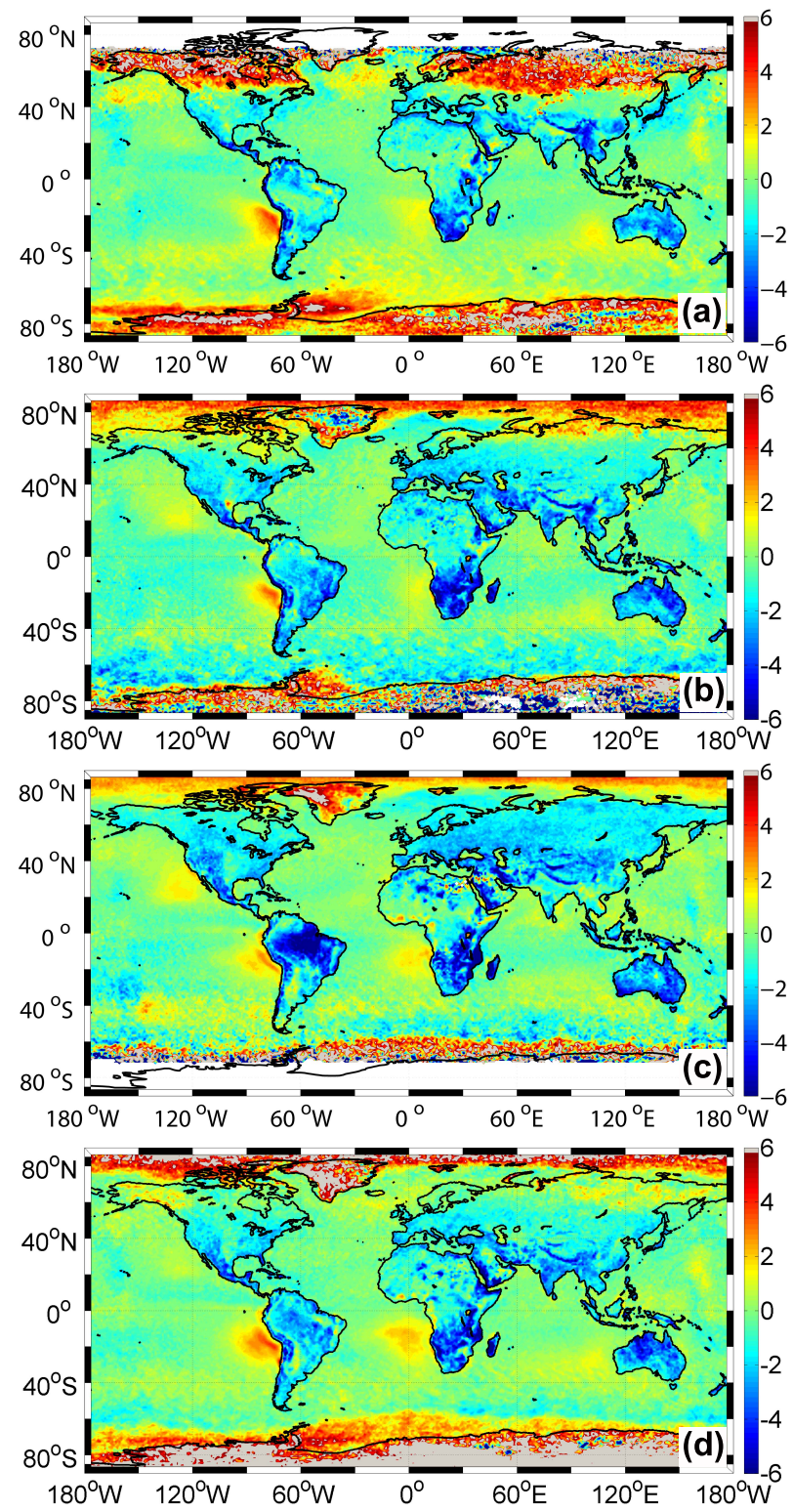

Fig. 2. Global distribution of 7-yr averaged morning minus afternoon values for liquid cloud optical thickness for (a) DecemberFebruary; (b) March-May; (c) June-August; and (d) SeptemberNovember.

\subsection{Over the oceans}

\subsubsection{Stratocumulus clouds}

Marine stratocumulus clouds occur over extensive areas of the extratropical oceans and play a central role in the global energy budget. Satellite imagery shows that marine stratiform clouds occur at high frequency, extensive spatial coverage and reflect much more sunlight than the darker underlying ocean surface (Randall et al., 1984). It has been estimated that the global cooling that would result from a $4 \%$ 
increase in the area covered by marine stratocumulus would offset the expected warming from doubling the atmospheric concentration of $\mathrm{CO}_{2}$ from the preindustrial period (Randall et al., 1984). Because these clouds have a powerful influence on the radiation budget primarily through their albedo, it is important to quantify the processes that control the diurnal cycle of their radiative properties.

Stratocumulus clouds generally lie to the east of the subtropical high pressure and their cloud depth, cloudiness, and marine boundary layer circulations are closely related to meteorological conditions (e.g. Schubert et al., 1979; Wakefield and Schubert, 1981; Wyant et al., 1997). Figure 1 demonstrates significant morning-to-afternoon reductions (i.e. Terra-Aqua, warm colors on the figure) in cloud cover over marine stratocumulus regions off the coast of California, Peru, and southern Africa. Such decreases in afternoon cloud cover is consistent with the previous reports showing that the largest cover for stratocumulus clouds is typically reached early in the morning ( $\sim 06: 00 \mathrm{LT})$ and decreases to a minimum value around 17:00 LT (Minnis et al., 1992; Rozendaal et al., 1995). Measured summertime (30 June-19 July) morning minus afternoon changes in CF between 10:00 LT and 13:00 LT off the coast of California in the vicinity of San Nicholas Island were $\sim 0.15$ to 0.2 (Minnis et al., 1992). This is in a good agreement with the morning-to-afternoon variation in CF over stratocumulus topped boundary layers off the coast of California observed by the two MODIS sensors (Fig. 1c). MODIS retrievals of morning-to-afternoon differences in cloud fraction measured off the coast of Peru and northern Chile (see Fig. 1d) are also consistent with the measurements conducted during the East Pacific Investigation of Climate (EPIC, 2001) stratocumulus cruise (9-24 October, 2001) (Bretherton et al., 2004).

In addition to $\mathrm{CF}$, observed morning-to-afternoon decreases in COT (Fig. 2) for selected stratocumulus regions agree with the previous reports (Minnis et al., 1992). For example, Fig. 2 shows that the largest morning-to-afternoon reduction in COT off the coast of Peru and northern Chile occurs away from the coast, in a region where large scale subsidence takes place year round, while a region very near the coast where the "upsidence wave" forms in the afternoon (e.g. Garreaud and Muñoz, 2004) exhibits noticeably different morning-to-afternoon changes in COT. Overall, Figs. 1 and 2 show that MODIS two sensors are capable of capturing some of the details in morning-to-afternoon variation of cloud properties and can be used for exploring the effects of different processes on short-term variation of stratocumulus clouds.

The characteristic diurnal cycle of marine stratocumulus has been described previously in numerous studies based on 1-D models (Nicholls, 1984; Turton and Nicholls 1987), LES (Lu and Seinfeld, 2005; Sandu et al., 2008), and field experiments, such as the First International Satellite Cloud Climatology Project (ISCCP) Regional Experiment (FIRE, 1987) (Betts, 1990; Hignett, 1991), the Atlantic Stratocumu- lus Transition Experiment (ASTEX, 1992) (Ciesielski et al., 2001), and the EPIC, 2001 (Bretherton et al., 2004). It was established that the marine stratocumulus shows considerable variations over a 24-h cycle: during nighttime the cloud layer gets thicker, while during daytime the cloud layer is partly decoupled from the surface layer, causing the cloud layer to become thinner (Nicholls, 1984). Such diurnal variation was suggested should be viewed as a typical property of this cloud type in the subtropics controlled primarily by cloud-radiation interaction (e.g. Nicholls, 1984; Minnis et al., 1992; Ciesielski et al., 2001). However, several additional processes resulting from dynamical forcing variables (e.g. large-scale subsidence and sea surface temperature) and increased concentration of pollution aerosols were also suggested could modulate diurnal variation of stratocumulus cloud properties (Bretherton and Wyant 1997; Ackerman et al. 2004; Lu and Seinfeld 2005; Sandu et al., 2008; Sandu et al., 2009). For example, Brenguier et al. (2003), through the second North Atlantic Regional Aerosol Characterization Experiment (ACE-2) measurements over the Atlantic, found that polluted clouds tended to be thinner than clean clouds. Twohy et al. (2005) found a weak anticorrelation between cloud geometrical thickness and particle concentration from three of the four cleanest cloud cases from Dynamics and Chemistry of Marine Stratocumulus-II (DYCOMS-II), an airborne measurement of stratocumulus clouds over the eastern Pacific Ocean off the coast of San Diego, California. The aerosol induced suppression of precipitation and subsequent enhancement of entrainment drying was proposed as the potential mechanism leading to the enhanced daytime reduction of cloud water (Ackerman et al., 2004; Lu and Seinfeld, 2005). Recent LES studies of low CCN (“clean”) and high CCN ("polluted") stratocumulus clouds confirmed this hypothesis showing that non-precipitating clouds with high droplet number concentration are typically characterized by larger water content at night and smaller during a day (Sandu et al., 2008, 2009). The year-round retrievals of aerosol and cloud properties by the MODIS sensors allow us to explore the morning-to-afternoon variation of stratocumulus cloud properties segregated by aerosol loadings and seasonality. Such analysis cannot resolve all the conceivable issues associated with the effects of meteorology and aerosol on diurnal variation of stratocumulus cloud properties; though, the large number of remotely sensed data involving many different climatic and weather conditions may reveal some of the main effects of aerosols on the short-term variation of clouds.

Figure 3 examines the relationship between AOD and morning-to-afternoon changes of marine stratocumulus cloud coverage and optical thickness for different seasons in three selected stratocumulus cloud regions CAL, PE and SAF. As CF and COT may themselves depend on seasonality (Supplementary material Figs. S3 and S4: http://www.atmos-chem-phys.net/9/3461/ 2009/acp-9-3461-2009-supplement.pdf) on Fig. 3 we plot morning-to-afternoon changes in $\mathrm{CF}$ and COT relative to 

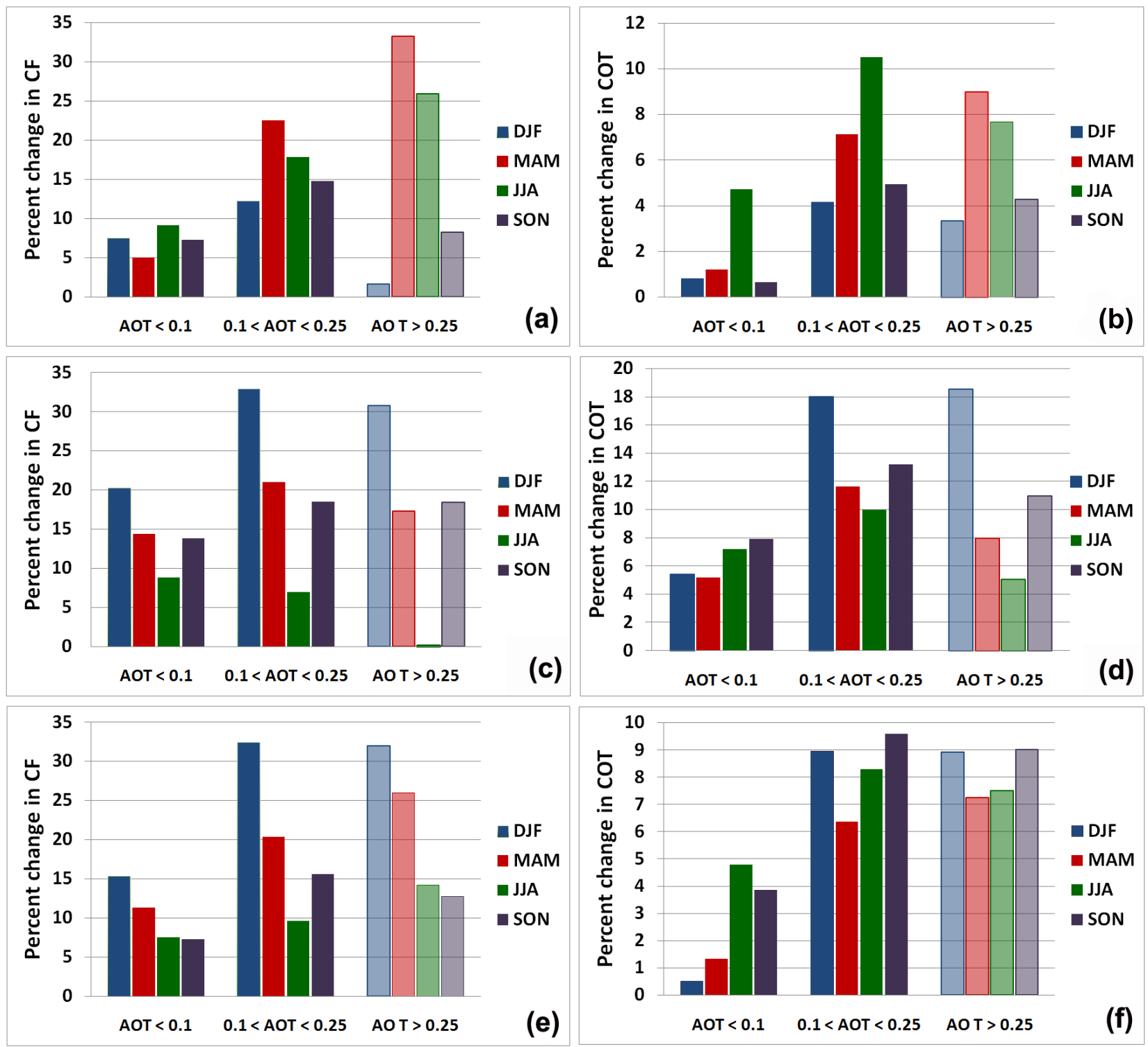

Fig. 3. The 7-yr averaged percent change in morning minus afternoon values for CF (left column) and COT (right column) relative to their value in the morning $(\Delta \mathrm{CF}($ Terra-Aqua)/CF Terra) and ( $\triangle \mathrm{COT}($ Terra-Aqua)/COT Terra $)$ for marine stratocumulus cloud in selected regions: (a), (b) west coast of California (CAL); (c), (d) Peru (PE); and (e), (f) southern Africa (SAF). Faded boxes show the seasons when limited number of observations cannot provide any conclusive assessment for the effect of aerosols on clouds and are only included for the completeness.

their value in the morning (from the Terra satellite). In order to assess the overall importance of each parameter on cloud properties, statistical data is summarized in Table 1.

The correlations between morning-to-afternoon changes in $\mathrm{CF}$ and COT, with AOD shown in Fig. 3 can serve as an indicator for the potential relationship between aerosol loadings and afternoon thinning of stratocumulus clouds. Figure 3 shows that for the clean clouds $(\mathrm{AOD}<0.1)$ there is $\sim 10$ to $20 \%$ reduction in afternoon cloudiness and 1 to $8 \%$ in optical thickness (positive Terra-Aqua differences). However, Fig. 3 also shows that transition of stratocumu- lus clouds from clean to moderately polluted case over the selected regions is typically associated with greater dissipation of the cloud layer (increased Terra-Aqua differences). According to Fig. 3 in moderately polluted case, within $3 \mathrm{~h}$ differences of MODIS crossing times, $\mathrm{CF}$ and COT can be reduced by 15 to $30 \%$ of their morning values, significantly higher compared to the clean conditions. Although Fig. 3 suggests that days characterized by elevated AODs may also be associated with enhanced afternoon reduction of clouds, it does not reveal if responses of clouds are due to the regional scale variation in $\mathrm{CCN}$ or dynamical forcing, as the 
Table 1. Summary of remotely sensed data of morning minus afternoon values for liquid cloud fraction $(\mathrm{CF})^{\mathrm{a}}$.

\begin{tabular}{|c|c|c|c|c|c|c|c|c|c|c|c|c|}
\hline \multicolumn{13}{|c|}{ California (CAL) } \\
\hline & \multicolumn{4}{|c|}{$\mathrm{AOD}<0.1$} & \multicolumn{4}{|c|}{$0.1 \leq \mathrm{AOD} \leq 0.25$} & \multicolumn{4}{|c|}{$0.25<\mathrm{AOD} \leq 0.8$} \\
\hline & Mean & Conf & $\mathrm{N}$ & $\begin{array}{c}\mathrm{N} / \mathrm{N}_{\max } \\
\%\end{array}$ & Mean & Conf & $\mathrm{N}$ & $\begin{array}{c}\mathrm{N} / \mathrm{N}_{\max } \\
\%\end{array}$ & Mean & Conf & $\mathrm{N}$ & $\begin{array}{c}\mathrm{N} / \mathrm{N}_{\max } \\
\%\end{array}$ \\
\hline DJF & 0.026 & $\begin{array}{l}0.0241 \\
0.0276\end{array}$ & 64967 & 32 & 0.042 & $\begin{array}{l}0.0398 \\
0.0445\end{array}$ & 52801 & 26 & 0.006 & $\begin{array}{c}-0.0018 \\
0.0133\end{array}$ & 5870 & 3 \\
\hline MAM & 0.022 & $\begin{array}{l}0.0188 \\
0.0244\end{array}$ & 19435 & 9 & 0.098 & $\begin{array}{l}0.0958 \\
0.1000\end{array}$ & 55583 & 26 & 0.144 & $\begin{array}{l}0.1395 \\
0.1492\end{array}$ & 11315 & 5 \\
\hline JJA & 0.056 & $\begin{array}{l}0.0535 \\
0.0581\end{array}$ & 33487 & 14 & 0.109 & $\begin{array}{l}0.1067 \\
0.1113\end{array}$ & 43194 & 18 & 0.158 & $\begin{array}{l}0.1485 \\
0.1677\end{array}$ & 2754 & 1 \\
\hline SON & 0.032 & $\begin{array}{l}0.0299 \\
0.0331\end{array}$ & 67380 & 27 & 0.064 & $\begin{array}{l}0.0618 \\
0.0656\end{array}$ & 70534 & 28 & 0.036 & $\begin{array}{l}0.0273 \\
0.0441\end{array}$ & 4615 & 2 \\
\hline \multicolumn{13}{|c|}{ Peru (PE) } \\
\hline & \multicolumn{4}{|c|}{$\mathrm{AOD}<0.1$} & \multicolumn{4}{|c|}{$0.1 \leq \mathrm{AOD} \leq 0.25$} & \multicolumn{4}{|c|}{$0.25<\mathrm{AOD} \leq 0.8$} \\
\hline & Mean & Conf & $\mathrm{N}$ & $\begin{array}{c}\mathrm{N} / \mathrm{N}_{\max } \\
\%\end{array}$ & Mean & Conf & $\mathrm{N}$ & $\begin{array}{c}\mathrm{N} / \mathrm{N}_{\max } \\
\%\end{array}$ & Mean & Conf & $\mathrm{N}$ & $\begin{array}{c}\mathrm{N} / \mathrm{N}_{\max } \\
\%\end{array}$ \\
\hline DJF & 0.112 & $\begin{array}{l}0.1103 \\
0.1138\end{array}$ & 75853 & 33 & 0.182 & $\begin{array}{l}0.1801 \\
0.1838\end{array}$ & 88877 & 39 & 0.170 & $\begin{array}{l}0.1628 \\
0.1780\end{array}$ & 5714 & 3 \\
\hline MAM & 0.072 & $\begin{array}{l}0.0706 \\
0.0735\end{array}$ & 111286 & 46 & 0.106 & $\begin{array}{l}0.1039 \\
0.1073\end{array}$ & 98063 & 40 & 0.087 & $\begin{array}{l}0.0793 \\
0.0941\end{array}$ & 5652 & 2 \\
\hline JJA & 0.049 & $\begin{array}{l}0.0476 \\
0.0504\end{array}$ & 139698 & 52 & 0.039 & $\begin{array}{l}0.0372 \\
0.0406\end{array}$ & 91015 & 34 & 0.001 & $\begin{array}{c}-0.0059 \\
0.0069\end{array}$ & 5884 & 2 \\
\hline SON & 0.089 & $\begin{array}{l}0.0868 \\
0.0909\end{array}$ & 67705 & 24 & 0.119 & $\begin{array}{l}0.1176 \\
0.1209\end{array}$ & 104693 & 37 & 0.119 & $\begin{array}{l}0.1140 \\
0.1239\end{array}$ & 10698 & 4 \\
\hline \multicolumn{13}{|c|}{ S. Africa (SAF) } \\
\hline & \multicolumn{4}{|c|}{$\mathrm{AOD}<0.1$} & \multicolumn{4}{|c|}{$0.1 \leq \mathrm{AOD} \leq 0.25$} & \multicolumn{4}{|c|}{$0.25<\mathrm{AOD} \leq 0.8$} \\
\hline & Mean & Conf & $\mathrm{N}$ & $\begin{array}{c}\mathrm{N} / \mathrm{N}_{\max } \\
\%\end{array}$ & Mean & Conf & $\mathrm{N}$ & $\begin{array}{c}\mathrm{N} / \mathrm{N}_{\max } \\
\%\end{array}$ & Mean & Conf & $\mathrm{N}$ & $\begin{array}{c}\mathrm{N} / \mathrm{N}_{\max } \\
\%\end{array}$ \\
\hline DJF & 0.080 & $\begin{array}{l}0.0780 \\
0.0829\end{array}$ & 34584 & 17 & 0.170 & $\begin{array}{l}0.1679 \\
0.1728\end{array}$ & 56497 & 27 & 0.168 & $\begin{array}{l}0.1604 \\
0.1759\end{array}$ & 7598 & 4 \\
\hline MAM & 0.050 & $\begin{array}{l}0.0479 \\
0.0515\end{array}$ & 64096 & 29 & 0.090 & $\begin{array}{l}0.0875 \\
0.0917\end{array}$ & 73152 & 33 & 0.114 & $\begin{array}{l}0.1077 \\
0.1202\end{array}$ & 11265 & 5 \\
\hline JJA & 0.042 & $\begin{array}{l}0.0404 \\
0.0440\end{array}$ & 72358 & 33 & 0.054 & $\begin{array}{l}0.0517 \\
0.0562\end{array}$ & 65700 & 30 & 0.070 & $\begin{array}{l}0.0750 \\
0.0837\end{array}$ & 23825 & 11 \\
\hline SON & 0.050 & $\begin{array}{l}0.0458 \\
0.0528\end{array}$ & 20236 & 9 & 0.105 & $\begin{array}{l}0.0617 \\
0.0656\end{array}$ & 50213 & 22 & 0.086 & $\begin{array}{l}0.0817 \\
0.0904\end{array}$ & 21317 & 9 \\
\hline
\end{tabular}

a Conf: $95 \%$ confidence interval for the mean, $\mathrm{N}$ - number of available grid point measurements for a given time period, $\mathrm{N}_{\text {max }}-\mathrm{maximum}$ number of potentially available measurements.

connection between AOD and morning-to-afternoon variation of CF and COT could also be a response to regionalscale changes in aerosols covarying with meteorological conditions. To examine the potential contribution of aerosols and dynamical forcing, we have selected a stratocumulus cloud region off the coast of Peru. According to Fig. 3 this area in subtropical southeast Pacific shows some of the largest morning-to-afternoon variation in $\mathrm{CF}$ and COT. Out of two main dynamical forcing variables, such as large-scale subsidence and sea surface temperature (SST) (e.g. Lu and
Seinfeld, 2005), we investigate the contribution from diurnally varying subsidence. Note that despite small variation between the two MODIS overpasses, changes in SST can still influence the amplitude and seasonal variation of morning-to-afternoon changes in stratocumulus cloud properties. Following the previous studies (e.g. Garreaud and Muñoz, 2004; Bretherton et al. 2004) mean vertical velocity at $850 \mathrm{mb}$ level is chosen as an indicator for the subsidence. The large-scale vertical pressure velocity (omega) at $850 \mathrm{mb}$ level was obtained from National Centers for Envi- 

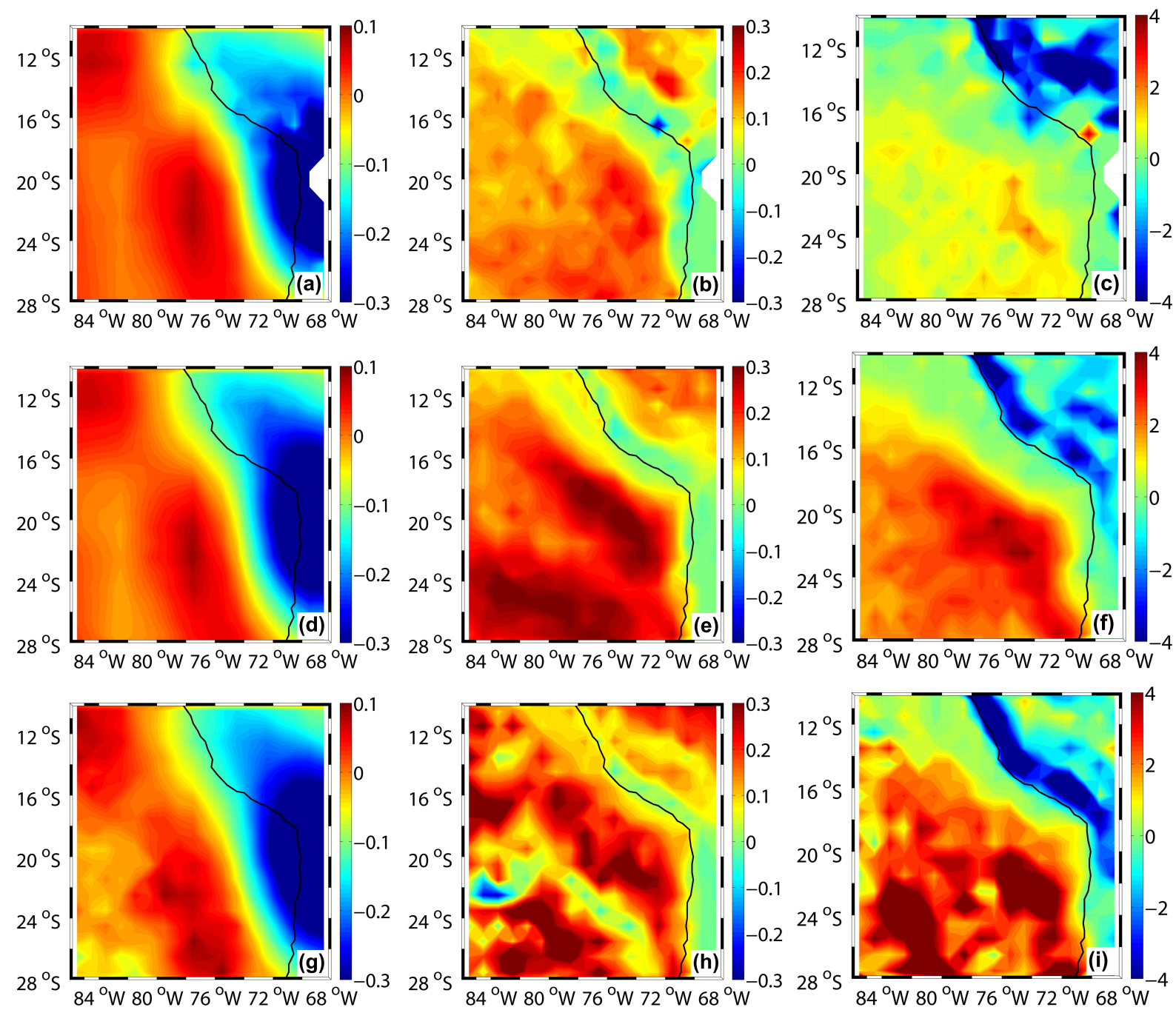

Fig. 4. The 7-yr averaged vertical pressure velocity ( $\mathrm{Pa} / \mathrm{s})$ (left column), CF (middle column) and COT (right column) for (a), (b), (c) clean (d), (e), (f) moderately polluted, and (g), (h), (i) heavily polluted cases. All data are averages for December-February season.

ronmental Prediction (NCEP) reanalysis data, regridded to $1^{\circ} \times 1^{\circ}$ resolution and separated based on MODIS retrieved AODs as clean, moderately polluted and heavily polluted. If the subsidence is solely responsible for the observed variation in morning-to-afternoon differences in cloud properties for different AOD cases, one expects to see the comparable variation in the magnitude of omega and the morning-toafternoon changes in cloud properties. Figure 4 shows 7 -year averaged omega fields $(\mathrm{Pa} / \mathrm{s})$ at 18:00 UTC (12:00-13:00 LT) and MODIS observed morning-to-afternoon differences in $\mathrm{CF}$ and COT segregated by the aerosol loading. While location and seasonality of the subsidence (regions with positive omegas) are in a general agreement with the detailed modeling studies (e.g., Garreaud and Muñoz, 2004), Fig. 4 does not indicate the robust relationship between the subsidence and the morning-to-afternoon variation in cloud properties for different aerosol loadings (see also Supplementary mate- rial Fig. S5: http://www.atmos-chem-phys.net/9/3461/2009/ acp-9-3461-2009-supplement.pdf). Considerable distinction in large-scale subsidence for different aerosol loadings was also not established for 12:00 and 18:00 UTC differences in omega fields (not shown). While it is practically impossible to fully separate aerosols from meteorology, and it has been established that climatic factors are controlling location and diurnal cycle of marine stratocumulus, our results indicate that increased aerosol concentration may lead to enhanced reduction of afternoon cloud coverage and optical thickness. This result is consistent with the recent modeling studies suggesting potential reduction of aerosol indirect forcing in polluted stratocumulus clouds (Ackerman et al., 2004; Lu and Seinfeld, 2005; Sandu et al., 2008, 2009).

Figures 3 and 4 also show that for the heavily polluted clouds $(0.25<\mathrm{AOD} \leq 0.8)$ there is no unique correlation between AOD and CF or COT. Several case studies for stra- 

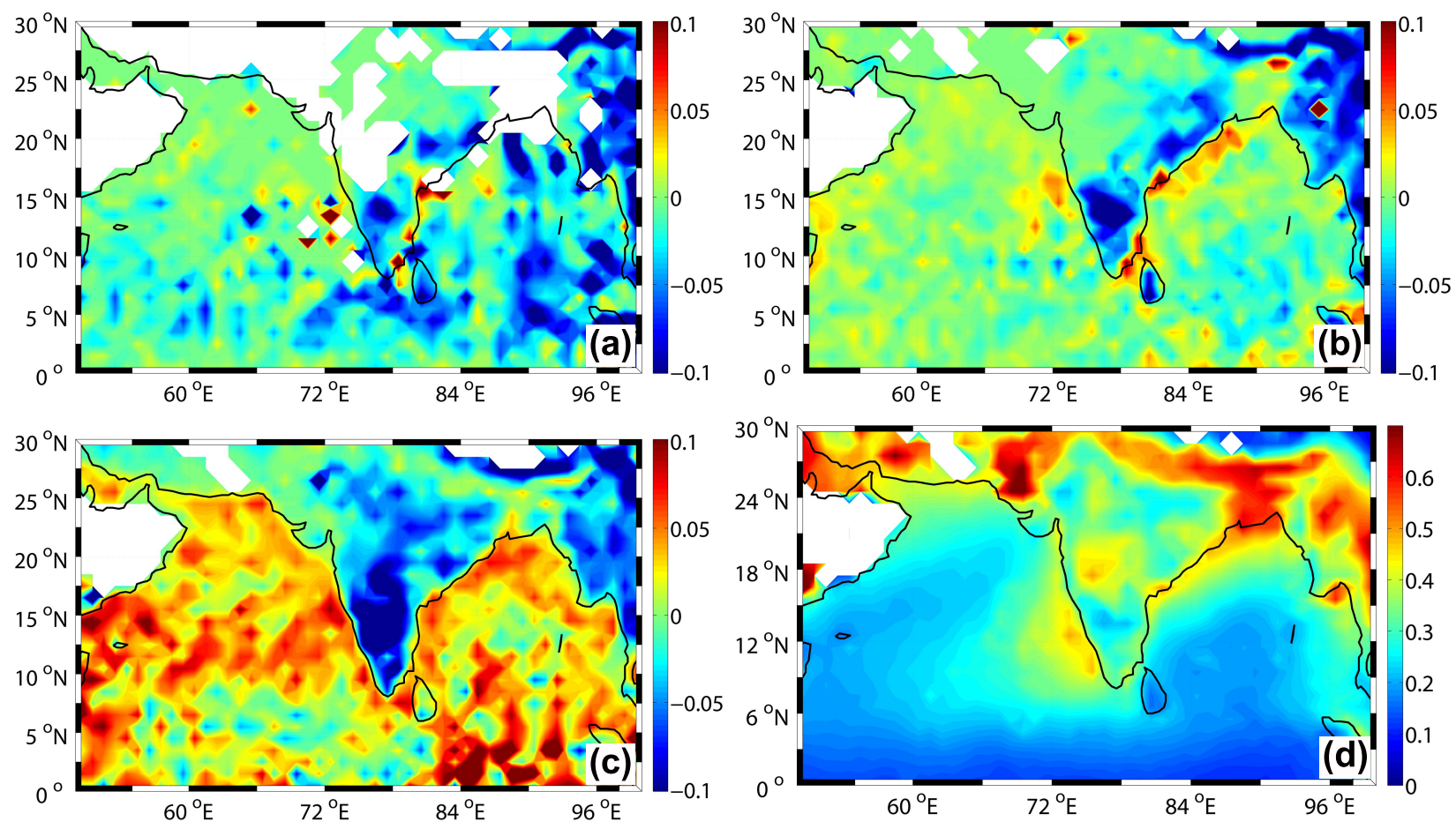

Fig. 5. Morning minus afternoon values for 7 -yr averaged trade wind cumuli cloud coverage for (a) clean, (b) moderately polluted, (c) heavily polluted cases and (d) Terra satellite retrieved AOD over the AS and the BoB during January-April period.

tocumulus clouds in study regions revealed, that while for the days with $\mathrm{AOD}<0.25$, aerosols are typically below marine stratocumulus cloud layers, elevated AOD episodes can be associated with the long range transported Asian (springtime for CAL region) or Saharan (wintertime for SAF region) aerosol that are advected aloft, above the stratus deck, with little interaction with the clouds below. Supplementary material Fig. S6 http://www.atmos-chem-phys.net/9/3461/2009/ acp-9-3461-2009-supplement.pdf shows several case studies for the aerosols inside and above marine stratocumulus cloud deck.

\subsubsection{Trade wind cumulus clouds}

Possible relationships between AOD and trade wind cumulus cloud coverage and optical thickness are examined over the AS and the BoB region. This part of the northern Indian Ocean was chosen for the analysis because it is often subjected to heavy air-pollution with a large fraction of absorbing black carbon aerosols (Ramanathan et al., 2001). This Indo-Asian haze could lead to a considerable reduction in afternoon cloud cover and decrease in aerosol-induced radiative cooling at the top of the atmosphere on a regional scale (Ackerman et al., 2000). Through their effect on clouds, these absorbing aerosols may influence the hydrological cycle, regional precipitation and even large scale atmospheric circulations (Ramanathan et al., 2001). The added impor- tance of this oceanic region is that it borders rapidly developing nations with the potential for large future increases in heavy pollution.

Observational and modeling studies for the time series of trade cumulus cloud coverage suggest that there is a natural diurnal variation in CF. Maximum cloudiness is typically reached before and near sunrise with subsequent reduction during the daytime to an afternoon minimum around the local noon (Betts et al., 1995; Ackerman et al., 2000) or between 16:00 and 18:00 LT (Brill and Albrecht, 1982). Compared to stratocumulus clouds, the observed morning-to-afternoon differences in cloud coverage for trade wind cumulus regime are smaller, typically between $0.10-0.15$ (Brill and Albrecht, 1982). Such variations in cloud cover primarily occur due to diurnal changes in the radiative forcing that could be strongly amplified by absorbing aerosols (Brill and Albrecht, 1982; Ackerman et al., 2000; Johnson, 2005).

To assess the effect of Indo-Asian haze on trade cumulus clouds on Fig. 5 we plot morning-to-afternoon variations of CF and Terra satellite retrieved AOD over the northern Indian Ocean during January-April season (JFMA). During this time clouds over AS and BoB are primarily classified as moderately or heavily polluted. Over the northern Indian Ocean, JFMA is the time for the northeast (NE) monsoon during which prevailing low-level winds flow from the heavily polluted land bringing a thick haze layer over most of the AS and BoB (Ramanathan et al., 2001; Ramachandran 


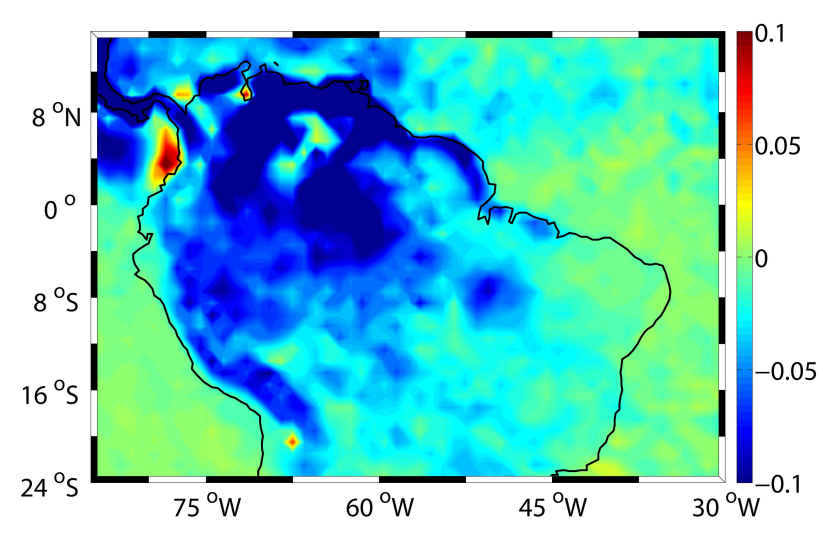

Fig. 6. Morning minus afternoon values for 7-yr averaged differences in ice cloud fraction over the Amazon basin for JulySeptember period.

and Jayaraman, 2002). The air masses in the northern part of the AS originate primarily from Saudi Arabia, Iran and Afghanistan, while over the southern AS the outflow occurs primarily from the Indian subcontinent (Rasch et al., 2001; Lelieveld et al., 2001). Over BoB, the highest concentration of aerosols is observed near the Indian subcontinent in the pathway by which smog drifts down India's populous Ganges valley and out into the Bay of Bengal (Lelieveld et al., 2001). This source of "atmospheric brown clouds" is advected over the Indian Ocean at altitudes between 1 and $3 \mathrm{~km}$ (Lelieveld et al., 2001; Ramanathan et al., 2007) and has an ample opportunity to interact with cumulus clouds in the region. Figure 5 shows that the morning-to-afternoon differences in CF during the JFMA period correlate with AODs and their outflow channels in the region (Fig. 5d). This result is in agreement with previous findings (e.g. McFarquhar et al., 2004) suggesting the dominance of semidirect over indirect effect of the Indo-Asian haze. Unlike cloud fraction, we did not find clear relationship between aerosol loadings and morning-to-afternoon variations of COT (not shown). Future studies for improved quantification of the effect of aerosols on trade wind cumulus clouds in northern Indian Ocean may consider separation of clean and polluted clouds by cloud dimensions. Heavily polluted clouds typically are more numerous but have smaller horizontal dimension (Xue et al., 2008). Satellite retrievals of COT for clean and heavily polluted trade cumulus clouds were shown to be almost indistinguishable for the cloud diameters less than $1 \mathrm{~km}$ (McFarquhar et al., 2004). Semidirect effect of aerosol on shallow cumulus clouds was also proposed to be very different for buoyant or "active" clouds that convect freely through the boundary layer and "passive" clouds that have diverged upon reaching the inversion (Johnson, 2005).

\subsection{Over the land}

It is significantly harder to interpret morning-to-afternoon variation cloud properties over land, since dynamic processes such as variation of boundary layer height, or local topography can easily influence cloud microphysical properties within the narrow time window of the two MODIS sensor overpasses. Nonetheless, looking at Figs. 1 and 2 some of the spatial patterns become evident. Over most of the low-latitude continental regions (excluding the tropical rain forests) Figs. 1 and 2 show slightly negative values (or no change) for morning-to-afternoon variation of $\mathrm{CF}$ and larger negative values for COT. This is mainly due to the initiation of natural convection that, compared to mostly cloud free skies in the morning, brings more clouds in the afternoon. Over the high latitudes, Figs. 1 and 2 show near neutral morning-to-afternoon variation for cloud fraction and negative values for COT, indicating that in these regions Terra overpass retrieves some late morning clouds that deepen through the afternoon (Aqua overpass) without significant changes in their horizontal extent. Figures 1 and 2 also show that morning-to-afternoon variations in $\mathrm{CF}$ over the three largest rainforests - the American, the African, and the Asian are very different from the rest of the land regions. The morning-to-afternoon variability in cloud cover and optical thickness and their possible relationship to AOD over the tropical rainforests will be examined here in more detail for the Amazon basin.

\subsubsection{The Amazon region}

The climate and circulation of the tropical Americas and the behavior of clouds and precipitation in the Amazon region have been investigated in a series of research papers (Greco et al., 1990; Garstang et al., 1994). The importance of diurnal convective forcing over the Amazon region was noted in observational studies (Foltz and Gray, 1979) and model results (Silva Dias et al., 1983, 1987). Figures 1 and 2 demonstrate large changes in morning-to-afternoon variation of $\mathrm{CF}$ and COT over the Amazon during the seasons of transition from wet to dry. Over the Amazon region the wet season is typically defined as November-May, while the dry season is from July to October. However, this definition of wet and dry seasons is not exact, as the onset of rain and amount of precipitation varies considerably over the different regions of the Amazon; e.g. the northwestern part of the region is located in the path of seasonal migration of the convective activity and has almost no dry season (Machado et al., 2004).

Under natural (clean) conditions typically observed during the rainy season, convection increases in the afternoon. This convection organizes not from the cloud-free skies but rather from the wide-spread small clouds with high cloud fraction and low COT that are prevalent in the morning. During the rainy season the minimum cloud cover occurs only a few hours before the maximum precipitation in the early 
afternoon, whereas maximum cloud cover occurs at night (Machado et al., 2002). During the afternoon, strong convective elements develop with low cloud fraction and large COT. These "convective towers" also produce high clouds (mainly cirrus), which cover a large fraction of the territory. Such conversion of a predominantly water cloud fraction in the morning into a predominantly ice cloud fraction in the afternoon is seen in Fig. 6 (see also Supplementary material Fig. S7: http://www.atmos-chem-phys.net/9/3461/2009/ acp-9-3461-2009-supplement.pdf). Note that Figs. 1 and 2 miss this conversion from water clouds to ice clouds because only water clouds are shown. Figure 6 also reveals possible smoke invigoration of convection over most of the BLA region, where increased AOD positively correlates with the afternoon enhancement (cold colors on Fig. 6) of the ice cloud fraction (IF). In the dry season, a lesser amount of convective available potential energy and a capping inversion suppress the deep convection and the organization of the shallow clouds into convective towers. Under such conditions in the dry season, the tropical rainforest demonstrates diurnal characteristics typical of other land forest regions (i.e. no change in CF and slight increase in COT).

How do aerosols affect this natural pattern seen in the Amazon? To explore the effect of aerosols on morning-toafternoon changes in cloud properties over the Amazon region, we examine the July-September time period. This time period was chosen, because it is associated with high aerosol content from biomass burning, natural biogenic emissions, and soil dust resuspension (Echalar et al., 1998; Zhang et al., 2008). Large contrasts in available precipitation between northern and the southern parts of the region also allow us to quantify aerosol effect on clouds during both rainy and dry conditions. Figure 7 shows that addition of aerosols can strongly influence morning-to-afternoon variation of clouds and amplify dissimilarities between the northern and the southern parts of the Amazon basin. According to this figure, the strong afternoon decrease (positive TerraAqua values) in warm cloud cover, characteristic of the wet season (see Fig. 1a, b), is now only visible in the far northern corner of the Amazon basin. This is the region with high rates of precipitation during this time period. The area along the southern and south eastern margin of the Amazon forest, known as the "arc of deforestation" due to widespread fire activity, demonstrates different behavior: slightly amplified afternoon cloudiness and considerable increase in water cloud optical thickness. Figure 7 also shows that with the addition of aerosols the typical contrast in morning-to-afternoon variation of cloud properties between the northern and the southern parts of the Amazon deepens.

Convection processes appear to intensify in moderately polluted and heavily polluted environments where we see the cloud cover of water clouds decrease and that of ice clouds increase between morning and afternoon. A conceptual model of how aerosol particles delay the onset of precipitation, raise the level of glaciation and ultimately lead to stronger convection is described in Rosenfeld et al. (2008). While previous observational results have also confirmed this model (Andreae et al., 2004; Koren et al., 2005) this is the first time we have seen MODIS satellite confirmation of the process occurring on a diurnal scale. We do not see the same dependence on AOD in the arc of deforestation, where convection is suppressed by the prevailing meteorology. Here the morning-to-afternoon pattern resembles typical patterns seen over other continental areas and does not appear to be affected by the addition of smoke. This does not preclude the effect of smoke on the overall cloud properties during this season and region; it only affects the changes from morning to afternoon.

\section{Conclusions}

A new technique for exploring morning-to-afternoon variability in cloud properties using the differences from the Terra and Aqua MODIS overpasses was developed in this study and used to assess the importance of aerosols on morning-to-afternoon variability of liquid clouds. Long-term statistics for the aerosol optical depth and cloud microphysical data obtained from the two MODIS sensors have been used to explore the influence of atmospheric aerosols on the morning-to-afternoon variability of warm clouds under maritime and continental regimes and different seasons. For the analysis we have selected large areas of marine stratocumulus and trade wind cumulus regions and tropical rainforest. Simultaneous retrievals of aerosol loadings and cloud properties by the MODIS sensor allowed us to explore morningto-afternoon variation of $\mathrm{CF}$ and COT for clean, moderately and heavily polluted clouds in different seasons. Analysis of remotely sensed data revealed that in the afternoon, under the natural conditions (i.e. clean case), stratus clouds become optically thinner with reduced cloud fraction. While climatology is the key process controlling diurnal variation of marine stratocumulus cloud properties, data analysis indicates that morning-to-afternoon difference in CF and COT could be amplified in the presence of aerosols. Such conclusion corroborates the conceptual picture for the difference in diurnal cycle of pristine and polluted marine stratocumulus clouds. Aerosol induced increase in cloud droplet number and suppression of precipitation may be responsible for enhanced daytime entrainment drying leading to larger morning-to-afternoon differences in cloud fraction and liquid water path. Although satellite retrievals of morning-toafternoon differences in stratocumulus clouds do not allow the full assessments of aerosol indirect climate forcing, this study demonstrates that aerosols could perturb diurnal variation of stratocumulus clouds over extensive areas and have a potential to reduce indirect cloud forcing. This forcing is not apparent in once-a-day views of the Earth.

Data analysis for the trade wind cumulus clouds over the northern Indian Ocean also demonstrated afternoon reduc- 

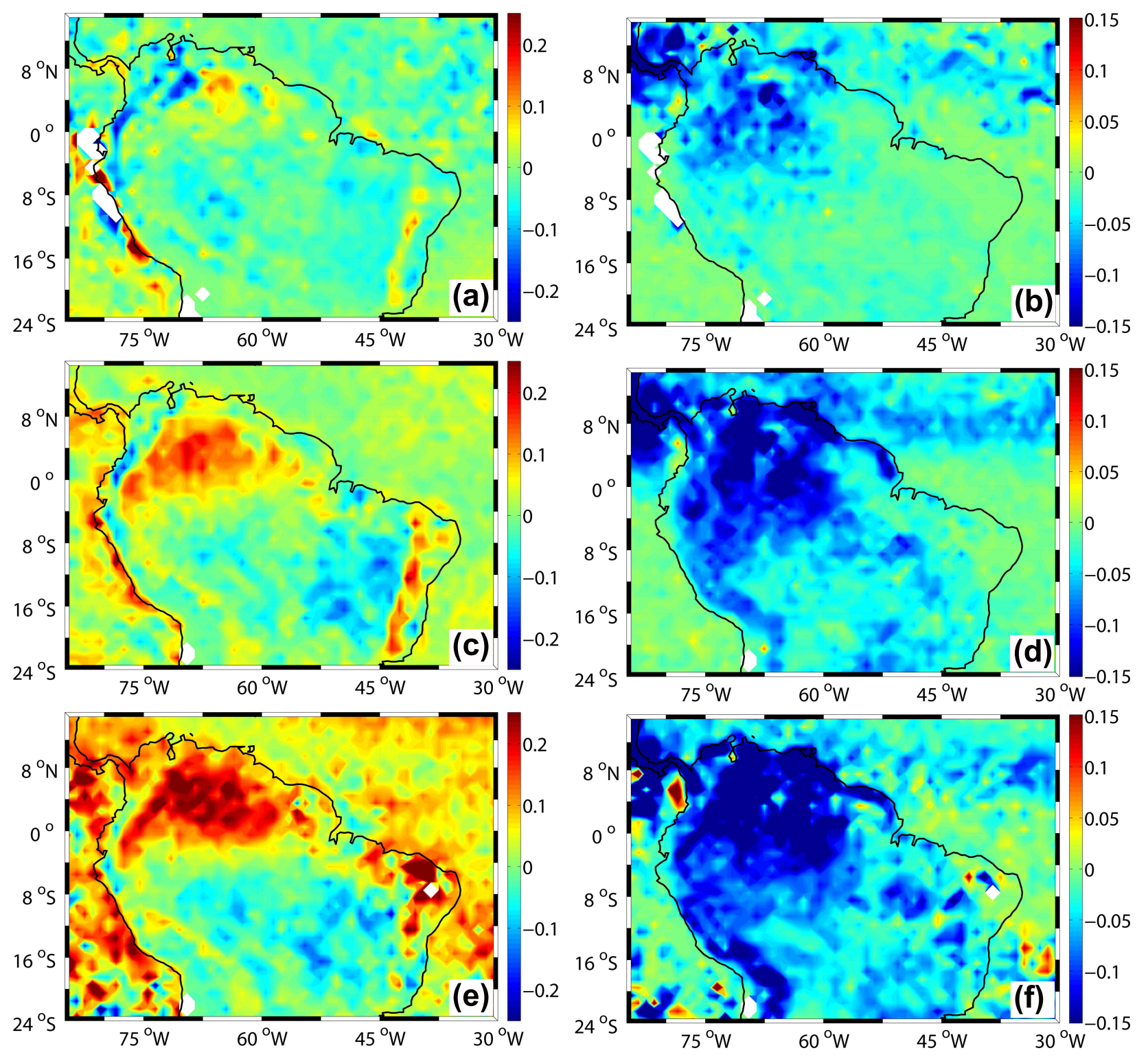

Fig. 7. Morning minus afternoon values for 7-yr averaged differences in liquid cloud fraction (left column) and ice cloud fraction (right column) over the Amazon basin for July-September period. Morning-to-afternoon differences are for (a), (b), clean (c), (d) moderately polluted, and (e), (f) heavily polluted clouds.

tion of CF with enhanced aerosol loadings, suggesting the dominance of semi-direct over indirect forcing of the IndoAsian haze. However, unlike stratocumulus clouds, no clear correlation between AOD and COT of trade cumulus clouds was established. Future studies should perhaps consider separation of trade cumulus clouds by their horizontal dimension and their convective activity.

Our analysis also revealed that morning-to-afternoon variation of $\mathrm{CF}$ and COT over the Amazon region is strikingly different between the northern part with typical dense rainforest and heavy precipitation and the southern and south eastern margins. This difference is further amplified by the presence of biomass burning aerosols that in the northern part of the Amazon basin are associated with strong reduction in the afternoon liquid cloud cover and optical thickness and concomitant increase in high (ice) fraction. Such change in morning-to-afternoon properties of clouds was explained by invigoration of convective clouds due to biomass burning aerosols. Results of our analysis demonstrate important warming potential of the Amazon smoke.

Aerosol-cloud interaction is a complex problem and all the mechanisms responsible for the morning-to-afternoon variation of cloud properties cannot be captured by the analysis of remotely sensed data offered in this study. Future research 
coupling satellite data analysis for diurnal variation of clouds with atmospheric models with detailed cloud microphysical and radiative properties will be necessary to fully explore the validity of our results. Nonetheless, we were able to show that the technique developed in this study can capture some of the major features resulting from dynamical forcing variables and aerosol-cloud interaction. Concomitant information about the aerosol loadings and cloud properties available from the MODIS sensors offers an unprecedented opportunity for exploring morning-to-afternoon variability of cloud properties and we expect that the technique proposed here will be used in the future for improved understanding of indirect and semi-direct effects of aerosols on clouds.

Acknowledgements. Meskhidze would like to acknowledge the support from National Aeronautics and Space Administration (NASA) Goddard Visiting Fellowship. Remer acknowledges support from the NASA Interdisciplinary Sciences Program.

Edited by: J. Quaas

\section{References}

Ackerman, A. S., Toon, O. B., Stevens, D. E., Heymsfield, A. J., Ramanathan, V., and Welton, E. J.: Reduction of tropical cloudiness by soot, Science, 288, 1042-1047, doi:10.1126/science.288.5468.1042, 2000.

Ackerman, A. S., Kirkpatrick, M. P., Stevens, D. E., and Toon. O. B.: The impact of humidity above stratiform clouds on indirect aerosol climate forcing, Nature, 432, 1014-1017, 2004.

Albrecht, B. A.: Aerosols, cloud microphysics, and fractional cloudiness, Science, 245, 1227-1230, doi:10.1126/science.245.4923.1227, 1989.

Anderson, T. L., Charlson, R. J., Winker, D. M., Ogren, J. A., and Holmén, K.: Mesoscale Variations of Tropospheric Aerosols, J. Atmos. Sci., 60, 119-136, 2003.

Andreae, M. O., Rosenfeld, D., Artaxo, P. A., Costa, A., Frank, G. P., Longo, K. M., and Silva-Dias M. A. F.: Smoking rain clouds over the Amazon, Science, 303, 1337-1342, doi:10.1126/science.1092779, 2004.

Barnes, W. L., Xiong, X., and Salomonson V. V.: MODIS instrument status and operational activities, Proc. SPIE Conf. Earth Observing Systems IX, 5542, 14-23, 2004.

Betts, A. K., Bretherton, C. S., and Klinker, E.: Relation between mean boundary-layer structure and cloudiness at the R /V Valdivia during ASTEX, J. Atmos. Sci., 52, 2752-2762, 1995.

Betts, A. K.: Diurnal variation of California coastal stratocumulus from two days of boundary layer soundings, Tellus, 42A, 302304, 1990.

Brenguier, J.-L., Pawlowska, H., and Schüller, L.: Cloud microphysical and radiative properties for parameterization and satellite monitoring of the indirect effect of aerosol on climate, J. Geophys. Res., 108(D15), 8632, doi:10.1029/2002JD002682, 2003.

Brennan, J. I., Kaufman, Y. J., Koren, I., and Li, R. R.: Aerosol Cloud Interaction - Misclassification of MODIS Clouds in Heavy Aerosol, IEEE Trans. Geosci. Remote Sens., 43, 911-915, 2005.
Bretherton, C. S. and Wyant, M. C.: Moisture transport, lowertroposphere stability, and decoupling of cloud-topped boundary, J. Atmos. Sci., 54, 148-167, 1997.

Bretherton, C. S., Uttal, T., Fairall, C. W., Yuter, S. E., Weller, R. A., Baumgardner, D., Comstock, K., and Wood, R.: The EPIC 2001 stratocumulus study, B. Am. Meteorol. Soc., 85, 967-977, 2004.

Bréon, F.-M., Tanré, D., and Generoso, S.: Aerosol effect on cloud droplet size monitored from satellite, Science, 295, 834-838, 2002.

Brill, K. and Albrecht, B.: Diurnal variation of the trade wind boundary layer, Mon. Weather Rev., 110, 601-613, 1982.

Ciesielski, P., Schubert, W. H., and Johnson, R. H.: Diurnal variability of the marine boundary layer during ASTEX, J. Atmos. Sci., 58, 2355-2376, 2001.

Devasthale, A., Kruger, O., and Grassl, H.: Change in cloud-top temperatures over Europe, IEEE Geosci. Remote Sens. Lett., 2, 333-336, doi:10.1109/LGRS.2005.851736, 2005.

Echalar, F., Artaxo, P., Martins, J. V., Yamasoe, M., Gerab, F., Maenhaut, W., and Holben, B.: Long-term monitoring of atmospheric aerosols in the Amazon Basin: Source identification and apportionment, J. Geophys Res., 103(D24), 31849-31864, 1998.

Erlick, C. and Schlesinger, D.: Another Look at the Influence of Absorbing Aerosols in Drops on Cloud Absorption: Large Aerosols, J. Atmos. Sci., 65(22), 661-669, 2008.

Esaias, W. E., Abbott, M. R., Barton, I., Brown, O. B., Campbell, J. W., Carder, K. L., Clark, D. K., Evans, R. H., Hoge, F. E., Gordon, H. R., Balch, W. M., Letelier, R., and Minnett, P. J.: An overview of MODIS capabilities for Ocean science observations, IEEE Trans. Geosci. Remote Sens., 36(4), 1250-1265, 1998.

Feingold, G., Jiang, H., and Harrington, J. Y.: On smoke suppression of clouds in Amazonia, Geophys. Res. Lett., 32, L02804, doi:10.1029/2004GL021369, 2005.

Feingold, G., Eberhard, W. L. Veron, D. E., and Previdi, M.: First measurements of the Twomey indirect effect using ground-based remote sensors, Geophys. Res. Lett., 30(6), 1287, doi:10.1029/2002GL016633, 2003.

Foltz, G. S. and Gray, W. M.: Diurnal variation in the troposphere's energy balance, J. Atmos. Sci., 36(8), 1450-1466, 1979.

Forest, C. E., Stone, P. H., Sokolov, A. P., Allen, M. R., and Webster, M. D.: Quantifying uncertainties in climate system properties with the use of recent climate observations, Science, 295, 113117, 2002.

Garstang, M., Massie Jr., H. L., Halverson, J., Greco, S., and Scala, J.: Amazon coastal squall lines, Part I: Structure and kinematics, Mon. Weather Rev., 122(4), 608-622, 1994.

Garreaud, R. D. and Muñoz, R.: The diurnal cycle in circulation and cloudiness over the subtropical southeast Pacific: A modeling study, J. Climate, 17, 1699-1710, 2004.

Greco, S., Swap, R., Garstang, M., Ulanski, S., Shipham, M., Harriss, R. C., Talbot, R., Andreae, M. O., and Artaxo, P.: Rainfall and surface kinematic conditions over central Amazonia during ABLE 2B, J. Geophys. Res., 95(D10), 17001-17014, 1990.

Han, Q., Rossow, W. B., and Lacis A. A.: Near-global survey of effective droplet radii in liquid water clouds using ISCCP data, J. Clim., 7(4), 465-497, 1994.

Hignett, P.: Observations of diurnal variation in a cloud capped marine boundary layer, J. Atmos. Sci., 48, 1474-1482, 1991.

Holben, B. N., Eck, T. F., Slutsker, I., Tanr'e, D., Buis, J. P., Set- 
zer, A., Vermote, E., Reagan, J. A., Kaufman, Y. J., Nakajima, T., Lavenu, F., Jankowiak, I., and Smirnov, A.: AERONET - A federated instrument network and data archive for aerosol characterization, Rem. Sens. Environ., 66, 1-16, 1998.

Hubanks, P. A., King, M. D., Platnick, S. A., and Pincus, R. A.: MODIS Atmosphere L3 Gridded Product Algorithm Theoretical Basis Document, MODIS Algorithm Theoretical Basis Document No. ATBD-MOD-30 for Level-3 Global Gridded Atmosphere Products (08_D3, 08_E3, 08_M3), online: http://modis-atmos.gsfc.nasa.gov/_docs/L3_ATBD_2008_ 12_04.pdf, 2008.

Johnson, B. T.: Large-eddy simulations of the semidirect aerosol effect in shallow cumulus regimes, J. Geophys. Res., 110, D14206, doi:10.1029/2004JD005601, 2005.

Johnson, B. T., Shine, K. P., and Forster, P. M.: The semi-direct aerosol effect: Impact of absorbing aerosols on marine stratocumulus, Q. J. Roy. Meteorol. Soc., 130(599), 1407-1422, doi:10.1256/qj.03.61, 2004.

Kaufman, Y. J. and Fraser, R. S.: The effect of smoke particles on clouds and climate forcing, Science, 277, 1636-1638, doi:10.1126/science.277.5332.1636, 1997.

Kaufman, Y. J., Koren, I., Remer, L. A., Rosenfeld, D., and Rudich, Y.: The effect of smoke, dust, and pollution aerosol on shallow cloud development over the Atlantic Ocean, Proc. Natl. Acad. Sci. USA, 102(32), 207-212, 2005a.

Kaufman, Y. J., Remer, L. A., Tanre, D., Rong-Rong, L., Kleidman, R., Mattoo, S., Levy, R. C., Eck, T. F., Holben, B. N., Ichoku, C., Martins, J. V., and Koren, I.: A critical examination of the residual cloud contamination and diurnal sampling effects on MODIS estimates of aerosol over ocean, IEEE Transact. Geosci. Rem. Sens., 43(12), 2886-2897, doi:10.1109/TGRS.2005.858430, 2005b.

King, M. D., Platnick, S., Moeller, C. C., Revercomb, H. E., and Chu, D. A.: Remote sensing of smoke, land, and clouds from the NASA ER-2 during SAFARI 2000, J. Geophys. Res., 108(D13), 8502, doi:10.1029/2002JD003207, 2003.

King, M. D., Kaufman, Y. J., Tanré, D., and Nakajima, T.: Remote sensing of tropospheric aerosols from space: Past, present, and future, B. Am. Meteorol. Soc., 80(11), 2229-2259, 1999.

Knutti, R., Stocker, T. F., Joos, F., and Plattner, G.-K.: Constraints on radiative forcing and future climate change from observations and climate model ensembles, Nature, 416, 719-723, 2002.

Koren, I., Martins, J. V., Remer, L. A., and Afargan, H.: Smoke invigoration versus inhibition of clouds over the Amazon, Science, 321, 846-949, 2008.

Koren, I., Kaufman, Y. J., Remer, L. A., and Martins, J. V.: Measurement of the effect of Amazon smoke on inhibition of cloud formation, Science, 303, 1342-1345, doi:10.1126/science.1089424, 2004.

Koren, I., Kaufman, Y. J., Remer, L. A., Rosenfeld, D., and Rudich, Y.: Aerosol invigoration and restructuring of Atlantic convective clouds, Geophys. Res. Lett., 32(14), L14828, doi:10.1029/2005GL023187, 2005.

Krüger, O. and Graß1, H.: Albedo reduction by absorbing aerosols over China, Geophys. Res. Lett., 31, L02108, doi:10.1029/2003GL019111, 2004.

Lelieveld, J., Crutzen, P. J., Ramanathan, V., Andreae, M. O., Brenninkmeijer, C. A. M., Campos, T., Cass, G. R., Dickerson, R. R., Fischer, H., de Gouw, J. A., Hansel, A., Jefferson, A., Kley, D., de Laat, A. T. J., Lal, S. Lawrence, M. G., Lobert, J. M., MayolBracero, O. L., Mitra, A. P., Novakov, T., Oltmans, S. J., Prather, K. A., Reiner, T., Rodhe, H., Scheeren, H. A., Sikka, D., and Williams, J.: The Indian Ocean experiment: Widespread air pollution from South and Southeast Asia, Science, 291, 1031-1036, doi:10.1126/science.1057103, 2001.

Lu, M.-L. and Seinfeld, J. H.: Study of the aerosol indirect effect by large-eddy simulation of marine stratocumulus, J. Atmos. Sci., 62, 3909-3932, 2005.

Machado, L. A. T., Laurent, H., and Lima, A. A.: Diurnal march of the convection observed during TRMM-WETAMC/LBA, J. Geophys. Res., 107(D20), 8064, doi:10.1029/2001JD000338, 2002.

Machado, L. A. T., Laurent, H., Dessay, N., and Miranda, I.: Seasonal and diurnal variability of convection over the Amazonia: a comparison of different vegetation types and large scale forcing, Theor. Appl. Climatol., 78(1-3), 61-77, doi:10.1007/s00704004-0044-9, 2004.

Martins, J. V., Tanré, D., Remer, L. A., Kaufman, Y. J., Mattoo, S., and Levy, R.: MODIS cloud screening for remote sensing of aerosol over oceans using spatial variability, Geophys. Res. Lett., 29(12), 8009, doi:10.1029/2001GL013252, 2002.

McFarquhar, G. M., Platnick, S., Di Girolamo, L., Wang, H., Wind, G., and Zhao, G.: Trade wind cumuli statistics in clean and polluted air over the Indian Ocean from in situ and remote sensing measurements, Geophys. Res. Lett., 31, L21105, doi:10.1029/2004GL020412, 2004.

Minnis, P., Heck, P. W., Young, D. F., Fairall, C. W., and Snider, J. B.: Stratocumulus cloud properties derived from simultaneous satellite and island-based instrumentation during FIRE, J. Appl. Meteor., 31(4), 317-339, 1992.

Nicholls, S.: The dynamics of stratocumulus, Quart, J. Roy. Meteor. Soc., 110, 821-845, 1984.

Penner, J. E., Dong, X. Q., and Chen, Y.: Observational evidence of a change in radiative forcing due to the indirect aerosol effect, Nature, 427, 231-234, doi:10.1038/nature02234, 2004.

Platnick, S., King, M. D., Ackerman, S. A., Menzel, W. P., Baum, B. A., Riedi, J. C., and Frey, R. A.: The MODIS cloud products: Algorithms and examples from Terra, IEEE Trans. Geosci. Remote Sens., 41(2), 459-473, doi:10.1109/TGRS.2002.808301, 2003.

Ramachandran, S. and Jayaraman, A.: Premonsoon aerosol mass loadings and size distributions over the Arabian Sea and the tropical Indian Ocean, J. Geophys. Res., 107(D24), 4738, doi:10.1029/2002JD002386, 2002.

Ramanathan, V., Ramana, M. V., Roberts, G., Kim, D., Corrigan, C., Chung, C., and Winker, D.: Warming trends in Asia amplified by brown cloud solar absorption, Nature, 448, 575-578, doi:10.1038/nature06019, 2007.

Ramanathan, V., Crutzen, P. J., Lelieveld, J., Althausen, D., Anderson, J., Andreae, M. O., Cantrell, W., Cass, G., Chung, C. E., Clarke, A. D., Collins, W. D., Coakley, J. A., and Dulac, F.: The Indian Ocean Experiment: An integrated assessment of the climate forcing and effects of the great Indo-Asian haze, J. Geophys. Res., 106(D22), 28371-28398, 2001.

Randall, D. A., Coakley, J. A., Fairall, C. W., Kropfli, R. A., and Lenschow, D. H.: Outlook for research on subtropical marine stratiform clouds, B. Am. Meteorol. Soc., 65, 1290-1301, 1984.

Rao, S. T., Zurbenko, I. G., Neagu, R., Porter, P. S., Ku, J. Y., and Henry, R. F.: Space and time scales in ambient ozone data, B. 
Am. Meteorol. Soc., 78, 2153-2166, 1997.

Rasch, P. J., Collins, W. D., and Eaton, B. E.: Understanding the Indian Ocean Experiment (INDOEX) aerosol distributions with an aerosol assimilation, J. Geophys. Res., 106(D7), 7337-7355, 2001.

Remer, L. A., Kaufman, Y. J., and Kleidman, R. G.: Comparison of three years of Terra and Aqua MODIS aerosol optical thickness over the global oceans, IEEE Geosci. Remote Sens. Lett., 3(4), 537-540, doi:10.1109/LGRS.2006.879562, 2006.

Remer, L. A., Kaufman, Y. J., Tanré, D., Mattoo, S., Chu, D. A., Martins, J. V., Li, R-R., Ichoku, C., Levy, R. C., Kleidman, R. G., Eck, T. F. Vermote, E., and Holben, B. N.: The MODIS aerosol algorithm, products, and validation, J. Atmos. Sci., 62(4), 947973, doi:10.1175/JAS3385.1, 2005.

Rosenfeld, D.: TRMM observed first direct evidence of smoke from forest fires inhibiting rainfall, Geophys. Res. Lett., 26(20), 31053108, 1999.

Rosenfeld, D.: Suppression of rain and snow by urban and industrial air pollution, Science, 287, 1793-1796, doi:10.1126/science.287.5459.1793, 2000.

Rosenfeld, D., Lohmann, U., Raga, G. B., O’Dowd, C. D., Kulmala, M., Fuzzi, S., Reissell, A., and Andreae, M. O.: Flood or drought: how do aerosols affect precipitation?, Science, 321, 1309-1313, doi: 10.1126/science.1160606, 2008.

Rozendaal, M., Leovy, C., and Klein, S. A.: An observational study of diurnal variations of marine stratiform cloud, J. Clim., 8(7), 1795-1809, 1995.

Schubert, W. H., Wakefield, J. S., Steiner, E. J., and Cox, S. K.: Marine stratocumulus convection, Part I: Governing equations and horizontally homogeneous solutions, J. Atmos. Sci., 36, 12861307, 1979.

Schwartz, S., Harshvardhan, E., and Benkovitz, C. M.: Influence of anthropogenic aerosol on cloud optical properties and albedo shown by satellite measurements and chemical transport modeling, Proc. Natl. Acad. Sci. USA, 99, 1784-1789, 2002.

Sandu, I., Brenguier, J. L., Geoffroy, O., Thouron, O., and Masson, V.: Aerosol impacts on the diurnal cycle of marine stratocumulus, J. Atmos. Sci., 65, 2705-2718, 2008.

Sandu, I., Brenguier, J.-L., Thouron, O., and Stevens, B.: How important is the vertical structure for the representation of aerosol impacts on the diurnal cycle of marine stratocumulus?, Atmos. Chem. Phys. Discuss., 9, 5465-5503, 2009, http://www.atmos-chem-phys-discuss.net/9/5465/2009/.

Silva Dias, P. L., Bonatti, J. P., and Kousky, V. E.: Diurnally forced tropical tropospheric circulation over South America, Mon. Weather Rev., 115(8), 1465-1478, 1987.
Silva Dias, P. L., Schubert, W. H., and DeMaria, M.: Largescale response of the tropical atmosphere to transient convection, J. Atmos. Sci., 40, 2689-2707, 1983.

Stevens, B., Vali, G., Comstock, K., Wook, R., Van Zanten, M. C., Austin, P. H., Bretherton, C. S., and Lenschow, D. H.: Pockets of open cells and drizzle in marine stratocumulus, B. Am. Meteorol. Soc., 86(1), 51-57, doi:10.1175/BAMS-86-1-51, 2005.

Tanré, D., Kaufman, Y. J., Herman, M., and Mattoo, S.: Remote sensing of aerosol properties over oceans using the MODIS/EOS spectral radiances, J. Geophys. Res., 102(D14), 16971-16988, 1997.

Turton, J. D. and Nicholls, S.: A study of the diurnal variation of stratocumulus using a multiple mixed-layer model, Quart. J. Roy. Meteor. Soc., 113, 969-1009, 1987.

Twohy, C. H., Petters, M. D., Snider, J. R., Stevens, B., Tahnk, W., Wetzel, M., Russell, L., and Burnet, F.: Evaluation of the aerosol indirect effect in marine stratocumulus clouds: Droplet number, size, liquid water path, and radiative impact, J. Geophys. Res. 110, D08203, doi:10.1029/2004JD005116, 2005.

Twomey, S.: The influence of pollution on the short wave albedo of clouds, J. Atmos. Sci., 34, 1149-1152, 1977.

Wakefield, J. S. and Schubert, W. H.: Mixed-layer mode simulations of eastern North Pacific stratocumulus, Mon. Weather Rev., 109, 1952-1968, 1981.

Wise, E. K. and Comrie, A. C.: Meteorologically adjusted urban air quality trends in the Southwestern United States, Atmos. Environ., 39, 2969-2980, 2005.

Wyant, M. C., Bretherton, C. S., Rand, H. A., and Stevens, D. E.: Numerical simulations and a conceptual model of the stratocumulus to trade cumulus transition, J. Atmos. Sci., 54, 168-192, 1997.

Xiong, X., Chiang, K.-F., Sun, J., Che, N., and Barnes, W. L.: Aqua MODIS first year on-orbit calibration and performance, Proc. SPIE Conf. Sensors, Systems and Next-Generation Satellites VII, 5234, 391-399, 2004.

Xue, H., Feingold, G., and Stevens, B.: Aerosol effects on clouds, precipitation, and the organization of shallow cumulus convection, J. Atmos. Sci., 65, 392-406, 2008.

Zhang, Y., Fu, R., Yu, H., Dickinson, R. E., Juarez, R. N., Chin, M., and Wang H.: A regional climate model study of how biomass burning aerosol impacts land-atmosphere interactions over the Amazon, J. Geophys. Res., 113, D14S15, doi:10.1029/2007JD009449, 2008. 